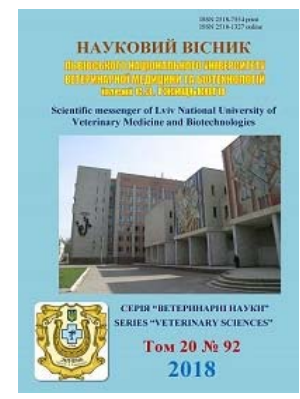

\author{
Науковий вісник Дьвівського національного університету \\ ветеринарної медицини та біотехнологій імені С.3. Гжицького
}

\author{
Scientific Messenger of Lviv National University \\ of Veterinary Medicine and Biotechnologies
}

ISSN 2518-7554 print

doi: 10.32718/nvlvet9201

ISSN 2518-1327 online

http://nvlvet.com.ua

UDC 612.395.2:591.133.1/2:613.25:636.8

\title{
Dietetic ingredients of small animals suffering from obesity and their biological role
}

\author{
L.-E. Al-Badu ${ }^{1}$, O. Smirnov ${ }^{2}$, L. Kalachniuk ${ }^{1}$ \\ ${ }^{1}$ National University of Life and Environmental Science of Ukraine, Kyiv, Ukraine \\ ${ }^{2}$ Institute of Animal Biology NAAS, Lviv, Ukraine
}

Article info

Received 08.10.2018

Received in revised form 05.11 .2018

Accepted 06.11.2018

National University of Life and Environmental Science of Ukraine, Heroiv Oborony Str.15, building 3, of. 207, Kyiv, 03041, Ukraine. Tel.: +38-063-581-53-31 E-mail: kalachnyuk_liliya@nubip. edu.ua

Institute of Animal Biology of NAAS, Stusa Str., 38, Lviv. 79000, Ukraine.
Al-Badu, L.-E., Smirnov, O., \& Kalachniuk, L. (2018). Dietetic ingredients of small animals suffering from obesity and their biological role. Scientific Messenger of Lviv National University of Veterinary Medicine and Biotechnologies, 20(92), 3-7. doi: 10.32718/nvlvet9201

Obesity is a medical condition in which excess body fat has accumulated to the extent that it may have a negative effect on health. The daily ration of an adult cat must contain 40-45\% of proteins, $20-25 \%$ of fats, $25-30 \%$ of carbohydrates. Low- fat diets are recommended to cats with overweight. Necessary amino acids are in the diet of cats with excess weight. Taurine is a sulfonic acid, which synthesizes in the body of animals and humans from the amino acid of cysteine. It plays an essential role in the digestion and assimilation of fats and lipids. The need for cats in taurine is due to their limited ability to synthesize taurine from amino acids that contain sulfur, as well as the fact that it holds bile acids. The latter is very important because cats do not produce bile acid salts associated with glycine, even in the case of taurine deficiency. Taurine has many fundamental biological roles, such as conjugation of bile acids, antioxidation, osmoregulation, membrane stabilization, and modulation of calcium signaling. It is essential for cardiovascular function, and development and function of skeletal muscle, the retina, and the central nervous system. The deficiency of taurine leads to degeneration of the retina and blindness, deafness, cardiomyopathy, disorders in the functioning of the immune and reproductive systems, suppression of neonatal growth, and the occurrence of birth defects. The recommended amount for a cat per day is 100-200 mg. L-Tryptophan is an $\alpha$-amino acid that is used in the biosynthesis of proteins. Together with vitamin B6, magnesium and niacin, tryptophan is responsible for the serotonin production in the brain (a mediator that regulates the activity of nerve cells and transmits signals between them). Also, tryptophan is involved in the production of hemoglobin and affects the reproductive function of animals. The recommended amount for a cat per day is $0.3 \mathrm{~g} / 1000 \mathrm{kcal}$ of energy value (EV). DL-methionine is a synthetic analog of natural methionine. Methionine is an essential amino acid for animals. As the substrate for other amino acids such as cysteine and taurine, and the important antioxidant glutathione, methionine plays a critical role in the metabolism and health of many species, including humans. Methionine is a source of sulfur that forms the keratin protein. Keratin is simply necessary for the health of the hair, skin, and claws of the animal. The recommended amount for a cat per day (methionine + cystine) is $1.5 \mathrm{~g} / 1000 \mathrm{kcal} \mathrm{EV}$. Nowadays the problem of overweight in small domestic animals, in particular in cats and dogs, is becoming more widespread. In order to prevent the spread of obesity, therapeutic rations should be balanced by all indicators, such as proteins, fats, carbohydrates, amino acids, minerals, and vitamins.

Key words: proteins and amino acids, carbohydrates, lipid compounds, vitamins, minerals.

\section{Складові компоненти раціону дрібних тварин за ожиріння та їх біологічна роль}

Є.Н. Аль-Баду ${ }^{1}$, О.О. Смірнов ${ }^{2}$, Л.Г. Калачнюк ${ }^{1}$

${ }^{1}$ Національний університет біоресурсів і природокористування Украӥни, м. Київ, Украӥна

${ }^{2}$ Інститут біології тварин НААН, м. Львів, Украӥна

Ожиріння - хронічне рецидивуюче захворювання, яке характеризується надлишковим накопиченням жирової тканини в організмі, обумовлене порушенням обміну речовин. В основі його лежить позитивний енергетичний баланс, тобто надходження енергї з 
калоріями їжі перевищує енерговитрати. У добовому рачіоні дорослої кішки обов'язково мають міститися: 40-45\% білків, 2025\% жирів, 25-30\% вуглеводів. Кішкам, щз мають надлишкову вагу, рекомендовані раціони з низьким вмістом жсиру. Необхідні амінокислоти в раціоні кішок з надмірною вагою. Таури́н - сульфокислота, шуо синтезується в організмі тварин та людини з амінокислоти цистеїну; відіграє суттєву роль у процесі травлення $і$ засвоєння жирів та ліпідів. Потреба кішок в таурині пов'язана з їх обмеженою здатністю синтезувати таурин із амінокіслот, які містят сіру, а також з тим, що його утримують жовчні кислоти. Рекомендована кількість для кішки на добу: 100-200 мг. L-триптофан - незамінна амінокислота, на основі якої утворюються інші речовини, які беруть участь в роботі живого організму. Рекомендована кількість для кішки на добу: 0,3 г/1000 ккал енергетичної иінності (ЕЦ). DL-метіонін - ие синтетичний аналог природного метіоніну. Метіонін - незамінна для тварин амінокислота. Метіонін - джерело сірки, яка формує білок кератин. Кератин необхідний для здоров'я волосяного, шкірного покриву $і$ кігтів тварини. Рекомендована кількість для кішки на добу (метионін + ичстин): 1,5 г/1000 ккал ЕЦ. Отже, для дрібних домашніх тварин з надлишковою вагою, зокрема у котів та собак, з метою запобігання поширення ожиріння терапевтичні та лікувальні раціони повинні бути відповідно збалансованими, особливо за такими складовими компонентами, як: протеїни, жири, вуглеводи, амінокислоти, мінеральні речовини, вітаміни.

Ключові слова: протеїни і амінокислоти, вуглеводи, ліпідні сполуки, вітаміни, мінеральні речовини.

\section{Ветуп}

Ожиріння - захворювання, за якого надлишковий накопичений жир у тілі несприятливо впливає на стан здоров'я, призводячи до зменшення середньої тривалості життя i/або збільшення проблем зі здоров'ям (Haslam and James, 2005). Ожиріння у домашніх тварин поширене в багатьох країнах. Кількість собак $з$ надмірною вагою та ожирінням у Сполучених Штатах складає від 23\% до 41\%, при цьому близько 5,1\% страждають від ожиріння (Lund et al., 2006). Рівень ожиріння у котів дещо вищий і складає 6,4\% (Haslam and James, 2005). В Австралії рівень ожиріння у собак, що проходять ветеринарний огляд, складає 7,6\% (McGreevy et al., 2005). Ризик ожиріння у собак $є$ пов'язаним із наявністю або відсутністю ожиріння у їхніх власників, однак такого зв'язку не спостерігалось між котами та їхніми власниками (Nijland et al., 2009).

У добовому раціоні здорової кішки обов'язково мають міститися: 40-45\% білків, 20-25\% жирів, 25-
30\% вуглеводів (Luhova et al., 2016). Кішкам, що мають надлишкову вагу, рекомендовані раціони з низьким вмістом жиру (Maliuk et al., 2016). Дедалі більше зустрічається випадків надлишкової ваги у домашніх котів та кішок. Перше, що вводиться у курс лікування - це дієтотерапія.

Комерційні раціони, рекомендовані для котів та кішок $з$ надлишковою вагою, мають схожий базовий склад. Метою роботи є детальний аналіз основних складових компонентів дієт, їх кількісного вмісту та біологічної ролі.

\section{Матеріал і методи досліджень}

За допомогою аналізу комерційних раціонів, представлених на зооветеринарному ринку України, було виділено основні їх компоненти для тварин (зокрема котів) з надмірною вагою та охарактеризовано їх біологічну роль (табл.).

\section{Таблиця}

Основні складові компоненти дієт для котів 3 надмірною вагою

\begin{tabular}{|c|c|c|c|c|c|}
\hline Протеїни & Жири & Вуглеводи & Вітаміни & $\begin{array}{l}\text { Мінеральні } \\
\text { речовини }\end{array}$ & Амінокислоти \\
\hline $\begin{array}{l}\text { Гідролізат тваринних біл- } \\
\text { ків/протеїну свійської птиці. }\end{array}$ & $\begin{array}{l}\text { Тваринний } \\
\text { жир }\end{array}$ & $\begin{array}{l}\text { Буряковий } \\
\text { жом }\end{array}$ & $\begin{array}{c}\text { Суміш } \\
\text { токоферолів }\end{array}$ & Залізо & Таурин. \\
\hline $\begin{array}{l}\text { Кукурудзяне/ пшеничне глютенове } \\
\text { борошно/ борошно із кукурудзяно- } \\
\text { го/пшеничного глютена/ кукурудзя- } \\
\text { на/пшенична клейковина, молота } \\
\text { кукурудза/ пшениця. }\end{array}$ & $\begin{array}{c}\text { Риб'ячий } \\
\text { жир }\end{array}$ & Жом цикорію & Вітамін А & Йод & L-карнітин \\
\hline Дегідратоване м’ясо птиці & $\begin{array}{l}\text { Кокосова } \\
\text { олія }\end{array}$ & $\begin{array}{l}\text { М'якоть } \\
\text { буряка }\end{array}$ & Вітамін D3 & Мідь & $\begin{array}{l}\text { L-лізину гід- } \\
\text { рохлорид }\end{array}$ \\
\hline Соєве борошно & $\begin{array}{l}\text { Рослинна } \\
\text { олія }\end{array}$ & $\begin{array}{c}\text { Рослинна } \\
\text { клітковина, } \\
\text { целюлоза }\end{array}$ & $\begin{array}{c}\text { Вітаміни } \\
\text { групи В }\end{array}$ & Марганець & DL- метіонін. \\
\hline \multirow[t]{2}{*}{ Зневоднений курячий яєчний білок } & $\begin{array}{l}\text { Кокосова } \\
\text { олія }\end{array}$ & $\begin{array}{l}\text { Витримка } \\
\text { томата }\end{array}$ & & Цинк & L-триптофан \\
\hline & & & & Селен & \\
\hline
\end{tabular}

Протеїни. 1) Гідролізат тваринних білків/протеїну свійської птиці. У сучасній промисловості є ряд способів розщеплення протеїнів, а саме: за допомогою кислоти, лугів або ензимів. Такі способи переробки застосовують 3 метою обробки сировини в легкодоступні для засвоєння організмом білки і амінокисло- ти. Гідролізат протеїну - це частково розщеплений білок, який представляє собою його фрагменти у вигляді олігопептидів. За розщеплення рослинного або тваринного білка отримують амінокислотні гідролізати, до складу яких входять кислоти, пептиди й інші компоненти. Білки піддають гідролізу, щоб вони кра- 
ще засвоювалися. Після того, як протеїни надходять 3 їжею в організм, великі білкові молекули розщеплюються за допомогою комплексу травних і внутрішньоклітинних ензимів (Kalachniuk et al., 2016).

2) Кукурудзяне/пшеничне глютенове борошно/ борошно iз кукурудзяного/пшеничного глютена/кукурудзяна/пшенична клейковина, молота кукурудза/ пшениця. Глютен (клейковина) (від лат. gluten - клей) - група запасаючих білків, виявлених в насінні злакових рослин, особливо пшениці, жита, вівса i ячменю. Термін “глютен” позначає білки фракції проламінів і глютелінів, причому велика частина глютену припадає на частку перших. Вміст глютену в пшениці, проламіни якої отримали назву гліадину, доходить до $80 \%$. Глютен у вигляді клейковини має велике значення в хлібопекарській промисловості, його вміст в борошні є чинником, що визначає такі характеристики тіста як пружність при змішуванні 3 водою, і служить критерієм визначення якості борошна (Sanz, 2010). Використовується для годівлі сільськогосподарських тварин та птиці. За калорійністю кукурудзяний глютен займає друге місце після жирів тваринного походження. Протеїн глютену відрізняється високим вмістом сульфурвмісних амінокислот метіоніну та цистину. В ньому також міститься достатня кількість лінолевої кислоти, що позитивно впливає на продуктивність тварин. За енергією 1 кг глютену $є$ еквівалентним 7 кг кукурудзи, а за протеїном 1кг рибного борошна.

3) Дегідратоване м'ясо птиці - це м'ясо, позбавлене вологи та вважається одним 3 найцінніших джерел протеїну.

4) Соєве борошно, яке $є$ цінним харчовим продуктом, що отримується з насіння сої або соєвого шроту. За вмістом білка і мінеральних речовин набагато випереджає інші види борошномельної продукції. У складі борошна $є$ такий корисний елемент, як вітамін B4, здатний запобігти утворенню камінців всередині жовчного міхура. Крім того, ця речовина відмінно нормалізує обмінні процеси (особливо жировий обмін), що сприяє швидкому і природному зниженню маси тіла.

5) Зневоднений курячий яєчний білок (сухий альбумін) є джерелом протеїну, який, на відміну від жовтка, містить дуже мало холестеролу і жирних кислот. Окрім того, в яєчному білку присутній магній, рибофлавін, калій, натрій. Мікроелементи, такі, як цинк, фосфор, мідь і кальцій, також присутні в яєчному білку. Ці елементи сприяють зміцненню кігтів, шерсті, зубів і кісток. Додамо, що яєчний альбумін багатий вітамінами B6, В12 і вітаміном D. На відміну від інших продуктів, яєчний білок практично не втрачає поживних властивостей при термічній обробці, а що стосується його енергетичної цінності, то в протеїні великого курячого яйця міститься всього 17 калорій (Kalachniuk et al., 2016).

Жири (Ліпідні сполуки). 1) Тваринні жири - це природні жири, які отримують 3 жирових і кісткових тканин, з яєць і молока ссавців і птахів, а також 3 деяких риб і плазунів. Велика частина жирів у тварин знаходиться зазвичай під шкірою і в сальнику. Жири є важливим енергетичним сховищем для організму, захищають нутрощі від механічних пошкоджень, підтримують стабільну температуру тіла, не залежно від температури зовнішнього середовища (Luhova and Kalachnyuk, 2015b). До тваринних жирів відносяться яловичий, баранячий, гусячий і інші види жирів, свиняче сало, а також найбільш уживаний молочний жир - вершкове масло. До його складу входить величезна кількість вітамінів А, Е, В і холестеролу, але в той же час воно добре засвоюється (до 85\%). До складу жирів наземних тварин входять триацилгліцероли насичених і ненасичених жирних кислот і серед них - олеїнова кислота. Жирні кислоти у вигляді триацилгліцеролів накопичуються в жирових тканинах (Luhova and Kalachnyuk, 2015a). У випадку необхідності внаслідок дії гормонів (адреналіну, норадреналіну, глюкагону й адренокортикотропіну) запускається процес ліполізу. Звільнені жирні кислоти виділяються в кровотік, по якому і потрапляють у клітини, яким потрібна енергія.

2) Риб'ячий жир - це харчова добавка, що отримується, як правило, з таких холодноводних риб, як: менхаден, лосось і форель. Риб'ячий жир багатий омега-3 жирними кислотами, а саме: ейкозапентаєновою і докозагексаєновою кислотами, які істотно впливають на біохімічні процеси в організмі, зменшуючи, наприклад, запалення. Риба, в свою чергу, отримує ці кислоти 3 водоростей, які є альтернативними джерелами незамінних жирних кислот. Водорості в майбутньому можуть стати основним джерелом омега-3 жирних кислот, оскільки популяція риб у світовому океані продовжує зменшуватися. Добавки, що містять риб'ячий жир, можуть бути корисні для домашніх тварин, які страждають від запальних захворювань, включаючи алергії, артрит, хвороби нирок, серця i багатьох видів раку. Жирні кислоти в риб'ячому жирі зменшують імовірність розвитку запалення (Luhova et al., 2016). Добавки, що містять риб'ячий жир, є одними 3 найбільш часто використовуваних у всій ветеринарній медицині, причому вони можуть застосовуватися як додатковий лікарський засіб, так і основний. Були проведені широкі дослідження застосування риб'ячого жиру у собак і кішок, які показали позитивні результати, особливо у випадку лікування у тварин алергії. Добавки риб'ячого жиру також застосовуються за: а) профілактики діабетичної нейропатії; б) терапії у боротьбі з ідіопатичною епілепсією; в) профілактиці й лікуванні серцевих аритмій; г) профілактиці i лікуванні аутоімунних захворювань (Smirnov et al., 2017). Домашні тварини з будь-яким типом запальних захворювань можуть отримати користь від застосування добавок (Luhova and Kalachnyuk, 2015), що містять риб'ячий жир. У цілому, більш важкі захворювання вимагають вищих доз, ніж легкі. У разі тяжких запальних захворювань риб'ячого жиру буде недостатньо, але з його допомогою можна збільшити ефект від інших терапевтичних засобів.

3) Кокосова олія - нечастий інгредієнт у кормах для собак і кішок, який належить до джерел насичених рослинних жирів, що містять багато средньоланцюгових жирних кислот (СЦЖК) і довголанцюгових триацилгліцеролів, які легко всмоктуються в кишечнику i забезпечують організм легкоперетравним i 
засвоюваним джерелом енергії. Вона на 40\% складається $з$ лауриновой жирної кислоти та містить багато такого важливого антиоксиданту, як вітамін Е.

4) Рослинна олія - продукт рослинного походження, отриманий шляхом екстракції з насіння або фруктів, які обробляються для використання в харчових цілях. Це може бути суміш будь-яких рослинних жирів - різної якості і ступеня очищення. Співвідношення Омега-6 і Омега-3 жирних кислот в будь-якому маслі визначає його поживну цінність і може істотно відрізнятися в залежності від сировини, з якого воно виготовлене. На думку дослідників, оптимальне співвідношення Омега-6 і Омега-3 кислот складає 1:1 та вище у раціонах 3 метою зниження надмірної ваги у котів. Однак ці дані потребують подальших досліджень (Smirnov et al., 2017).

Вуглеводи. 1) Буряковий жом є джерелом розчинної клітковини.

2) Жом цикорію - це нерозчинні волокна кореня цикорію, що залишаються після приготування екстракту 3 цієї рослини. Це клітковина, яка містить деяку залишкову кількість розчинного пребіотика інуліну, кількість якого в цілісному корені є близько 50\%.

3) М'якоть буряка є джерелом розчинної клітковини.

4) Витримка томата - це подрібнена суміш шкіри, м'якоті і насіння томатів, яка залишається після виробництва кетчупів, соку, супів та $\epsilon$ неоднозначним інгредієнтом у плані користі для тварин. Місце цього складника у кормі дуже неоднозначне, але у невеликих кількостях томатні витримки сприяють утримуванню води в організмі та формуванню калових мас, тому, якщо цей інгридієнт знаходиться у невеликій кількості, тобто в кінці складу продукту, то він ніякої шкоди не викликає, а тільки сприяє стабілізації стану організму.

5) Рослинна клітковина, целюлоза. Природним джерелом клітковини $є$ целюлоза, яка очищеною i механічно подрібненою частиною м'якоті (клітинних стінок) різних волокнистих рослин та зазвичай використовується для зменшення відчуття голоду, а також виведення шерсті тварини з їі травного каналу.

Вітаміни. 1) Суміш токоферолів. Натуральна суміш з токоферолу і екстракту розмарину звичайного $\epsilon$ комплексом натуральних антиоксидантів для захисту готового корму від псування. 2) Вітамін 3) Вітамін D3 4) Вітаміни групи В.

Мінеральні речовини: залізо, йод, мідь, марганець, цинк, селен.

Амінокислоти: таурин, L-карнітин, L-лізину гідрохлорид, DL-метіонін, L-триптофан.

Вітаміни $i$ мінерали. Найрозповсюдженішими вітамінами у комерційних кормах є вітаміни груп А, B, $\mathrm{E}, \mathrm{D}$, а також такі мінерали, як залізо, йод, мідь, марганець, цинк, селен. Вітамін А, покращує захисні властивості слизових оболонок. Міститися в печінці, яєчному жовтку, вершковому маслі, сирому м'ясі, субпродуктах. Дефіцит вітаміну А призводить до затримок розвитку опорно-рухового апарату, дисфункції шлунково-кишкового тракту, зниження апетиту, погіршення загального стану вихованця. Великій відсоток міститься саме у риб'ячому жирі.
Серед вітамінів групи В важливу роль відіграє вітамін В1 (тіамін), оскільки забезпечує нормальну діяльність нервової системи кішки, їі м'язів і травлення. Вітамін В12 відповідає за нормальну роботу печінки і нервової системи, при його відсутності можуть виникнути проблеми 3 кров'ю. Дефіцит вітаміну В6 (піридоксин) в організмі кішки може спровокувати розвиток анемії і ураження нирок. Молодим тваринам, кошенятам необхідні вітаміни для кошенят вітамін В2 (рибофлавін) і вітамін D - для нормального росту і розвитку (Luhova and Kalachnyuk, 2016). Від вітаміну Е залежать процеси регенерації в організмі нашого вихованця, засвоєння жирів і уповільнення окислювальних процесів, а його дефіцит призводить до безпліддя у кішок і паралічу у котів. Для підтримки необхідного балансу кішка повинна вживати пророщену пшеницю, олію, пивні дріжджі.

\section{Результати та їх обговорення}

3 аналізу дієтичних кормів для кішок з надмірною вагою можна виділити такі необхідні амінокислоти, як: таурин, триптофан і метіонін.

Таури́н (лат. Taurinum) - сульфокислота, що синтезується в організмі тварин та людини з амінокислоти цистеїну; відіграє суттєву роль у процесі травлення і засвоєння жирів та ліпідів. Один $з$ основних компонентів жовчі, в невеликих кількостях міститься в різних тканинах тварин і людин, в основному в м'язах. Потреба кішок у таурині пов'язана 3 їх обмеженою здатністю синтезувати таурин із сульфурвмісних амінокіслот, а також $з$ тим, що його утримують жовчні кислоти. Останнє має велике значення, тому що кішки не виробляють солей жовчних кислот, які зв'язуються 3 гліцином, навіть у випадку дефіциту таурину (Simpson et al., 1993). Дефіцит таурину призводить до дегенерації сітківки і сліпоти, глухоти, кардіоміопатії, порушень в роботі імунної і статевої систем, пригнічення неонатального росту і виникнення вроджених вад, тому його рекомендована кількість для кішки на добу: 100-200 мг (Simpson et al., 1993).

L-триптофан (Tryptophan) - незамінна амінокислота, на основі якої утворюються інші речовини, які беруть участь у роботі живого організму. Разом 3 вітаміном В6, магнієм і ніацином триптофан відповідає за продукцію в мозку серотоніну (медіатора, який регулює активність нервових клітин і передає між ними сигнали). Також триптофан бере участь у формуванні гемоглобіну та впливає на репродуктивну функцію тварин. Природними джерелами триптофану $\epsilon$ м'ясо птиці, риба, молоко, сир, йогурт. Також його можна знайти в ряді зернових і деяких рослинних продуктах (грибах, бобових). За нестачі триптофану у тварин спостерігається поганий апетит, прогресуюча худоба, анемія i, слідчо, пригнічення функції ендокринних залоз і імунітету. Рекомендована кількість для кішки на добу: 0,3 г/1000 ккал енергетичної цінності (ЕЦ).

DL-метіонін - це синтетичний аналог природного метіоніну. Метіонін (Methionine) - незамінна для тварин амінокислота. Вона розщеплює жири, допомагаючи печінці ефективно справлятися 3 навантажен- 
ням. Метіонін - джерело Сульфуру, який формує протеїн кератин, що є необхідним для здоров'я волосяного, шкірного покриву і кігтів тварини. За нестачі метіоніну у людини і тварини знижується імунітет, погіршуються показники крові, відбувається атрофія мускулатури, порушуються функції головних фільтрів - печінки і нирок. У домашніх вихованців нестача метіоніну відразу помітна: кошенята і щенята погано ростуть, а їх шерсть виглядає тьмяною, слабкою i млявою. I головне: сульфурвмісна амінокислота метіонін, присутня тільки у протеїнах тваринного походження (особливо їі багато в яйцях, рибі і молочних білках). Рекомендована його кількість для кішки на добу (метионін + цистин): 1,5 г/1000 ккал ЕЦ (Simpson et al., 1993).

\section{Висновки}

На даний час проблема надлишкової ваги у дрібних домашніх тварин, зокрема у котів та собак, стає дедалі більш розповсюдженою. Тому, для запобігання поширення ожиріння терапевтичні та лікувальні раціони мають бути збалансованими за такими складовими компонентами, як: протеїни, жири, вуглеводи, амінокислоти, мінеральні речовини, вітаміни.

Перспективи досліджень: подальше вивчення впливу на організм хворої тварини відповідних раціонів 3 метою визначення оптимальних концентрацій поживних речовин у кормах та виявлення їх впливу за надлишку чи недостачі. Звідси, отримаємо відповідне обгрунтування для встановлення чи споживання певного раціону буде протипоказаним чи ні.

\section{References}

Haslam, D.W., \& James, W.P. (2005). Obesity. Lancet 366. PMID 16198769. doi: 10.1016/S01406736(05)67483-1.

Kalachniuk, L.H., Luhova, Ye.S., \& Maliuk, I.M. (2016). Protein metabolism in small animals with chronic renal failure and its correction. Eureka: Life Sciences (Estonia, Tallinn), 5(5), 3-7. doi: 10.21303/25045695.2016.00223.

Luhova, Ye., \& Kalachnyuk, L. (2015). Biochemical indexes in laboratory diagnosis of chronic renal failure of small animals. Youth and Progress of Biology: Book of abstracts of XI International Scientific Conference for Students and PhD Students (Lviv, 20-23 April 2015) Lviv, 474-475.

Luhova, Ye., \& Kalachnyuk, L. (2016). Proteinuria in the cats with chronic kidney disease and its correction. 2nd International Scientific Conference of the Veterinary Medicine Students, Faculty of Veterinary Medi- cine, Warsaw University of Life Science, Poland, May, 15th 2016, Abstract Book, Warsaw University of Life Science, 47.

Luhova, Ye.S, \& Kalachnyuk, L.G. (2015) Chronic renal insufficiency of small animals, and arterial hypertension. Scientific Messenger of LNU of Veterinary Medicine and Biotechnologies. Series "Veterinary Sciences", 17, 2(62), 130-133 (in Ukrainian).

Luhova, Ye.S, \& Kalachnyuk, L.G. (2015) Stages of chronic renal disease in small Scientific Messenger of LNU of Veterinary Medicine and Biotechnologies. Series "Veterinary Sciences", 17, 1(61), 2, 92-94 (in Ukrainian).

Luhova, Ye.S., Prys-Kadenko, V.O., Kulichenko, A.O., \& Kalachniuk, L. (2016) Diet-therapy of small animals with chronic renal failure. Scientific Messenger of LNU of Veterinary Medicine and Biotechnologies. Series "Veterinary Sciences", 18, 3(70), 178-180. doi: 10.15421/nvlvet7042 (in Ukrainian).

Lund, E.M., Armstrong, P.J., Kirk, C.A., \& Klausner, J.S. (2006). Prevalence and Risk Factors for Obesity in Adult Dogs from Private US Veterinary Practices. Intern J Appl Res Vet Med, 4(2), 177-186. http://jarvm.com/articles/Vol4Iss2/Lund.pdf.

Maliuk, I., Kulichenko, A., \& Kalachnyuk, L. (2016). Search of effective therapeutic agents of diabetes treatment in dogs and cats. Youth and Progress of Biology: Book of abstracts of XII International Scientific Conference for Students and PhD Students (Lviv, 19-21 April 2016) Lviv, 319-320.

McGreevy, P.D., Thomson, P.C., Pride, C., Fawcett, A., Grassi, T., \& Jones, B. (2005). Prevalence of obesity in dogs examined by Australian veterinary practices and the risk factors involved. Vet. Rec. 156(22), 695-702. https://www.ncbi.nlm.nih.gov/pubmed/15923551.

Nijland, M.L., Stam, F., \& Seidell, J.C. (2009). Overweight in dogs, but not in cats, is related to overweight in their owners. Public Health Nutr, 13(1), 1-5. PMID 19545467. doi: 10.1017/S136898000999022X.

Simpson, J.W., Anderson, R.S., \& Markwell, P.J. (1993). Clinical Nutrition of the Dog and Cat. Blackwell Scentific Publications, Oxford, 33-74.

Smirnov, O.O., Spivak, Yu.V., Smirnova, M.S., \& Kalachniuk, L.H. (2017) Indicators of protein-lipid exchange for hepatostateatosis. Scientific Messenger of LNU of Veterinary Medicine and Biotechnologies. Series "Veterinary Sciences", 19(78), 191-193. https://nvlvet.com.ua/index.php/journal/article/view/1 323 (in Ukrainian).

Sanz, Y. (2010). Effects of a gluten-free diet on gut microbiota and immune function in healthy adult humans. Gut Microbes, 1(3), 135-137. doi: 10.4161/gmic.1.3.11868. 